\title{
Annexin A2 inhibition suppresses ovarian cancer progression via regulating $\beta$-catenin/EMT
}

\author{
YAN LIU ${ }^{1}$, HONGYU LI $^{1}$, ZHENYING BAN $^{2}$, MANMAN NAI $^{1}$, \\ LI YANG $^{1}$, YANNAN CHEN ${ }^{1}$ and YIMING XU ${ }^{1}$ \\ Departments of ${ }^{1}$ Gynecology and ${ }^{2}$ Pathology, The Third Affiliated Hospital \\ of Zhengzhou University, Zhengzhou, Henan 450000, P.R. China
}

Received October 4, 2016; Accepted March 16, 2017

DOI: $10.3892 / o r .2017 .5578$

\begin{abstract}
Annexin A2 is a member of the Annexin family that acts as a $\mathrm{Ca}^{2+}$-dependent phospholipid and membrane binding protein, which is associated with the survival and spread of multiple neoplasms. However, the function of Annexin A2 in ovarian cancer progression remains unclear. In this study, we aimed to investigate the role and underlying molecular mechanism of Annexin A2 in cell proliferation and invasion in ovarian cancer. We found that the mRNA expression of Annexin A2 was upregulated in ovarian cancer tissues and cell lines. In the loss-of-function of Annexin A2, $\beta$-catenin was indicated to be significantly suppressed and EMT constrained. Moreover, cell proliferation and invasion were both markedly inhibited by the downregulation of Annexin A2. Additionally, the overexpression of $\beta$-catenin obviously reversed the effect of Annexin A2 on EMT, and cell proliferation and invasion, indicating that Annexin A2 suppression regulated EMT through controlling $\beta$-catenin. Taken together, this study showed that Annexin A2 inhibition suppresses proliferation and invasion in ovarian cancer via $\beta$-catenin/EMT, proposing the potential role of Annexin A2 in the prevention and treatment of ovarian cancer.
\end{abstract}

\section{Introduction}

Ovarian cancer ranks among the most lethal of gynecological malignancies (1-3). Symptoms of early ovarian cancer are

Correspondence to: Dr Hongyu Li, Department of Gynecology, The Third Affiliated Hospital of Zhengzhou University, 7 Kangfu Sreet, Zhengzhou, Henan 450000, P.R. China

E-mail: hongyulihyl@163.com

Abbreviations: EMT, epithelial-to-mesenchymal transition; RT-qPCR, real-time quantitative polymerase chain reaction; PVDF, polyvinylidene fluoride membrane; PBS, phosphate-buffered saline; BrdU, bromodeoxyuridine; MTT, 3-(4,5-dimethylthiazol-2-yl)-2,5-diphenyltetrazolium bromide; GAPDH, glyceraldehyde-3-phosphate dehydrogenase

Key words: Annexin A2, ovarian cancer, proliferation, invasion, $\beta$-catenin, epithelial-to-mesenchymal transition not obvious, and $70-80 \%$ patients with ovarian cancer are diagnosed at the advanced or terminal stage (4). In addition, ovarian cancer has a low 5-year survival rate (1,5). Invasion and proliferation are the significant attributes of malignant cancer that result in high mortality in ovarian cancer. Thus far, the underlying molecular mechanism of ovarian cancer remains unclear. A better understanding of the underlying mechanism of the invasion and proliferation in ovarian cancer could provide novel insights for the treatment of ovarian cancer.

Annexin A2, which is also known as Annexin II, p36, p39 and lipocortin II, is a member of the Annexin family (6-8). The Annexin family is a $\mathrm{Ca}^{2+}$-dependent phospholipid and membrane binding protein family (9). Annexin A2 is present in human endothelial cells, monocytes, macrophages, neuron, and some tumor cells $(8,10-12)$. The transformed cells express high levels of Annexin A2, and the terminally differentiated cells have low expression of Annexin A2 (13). In the cells of tumors such as breast, liver, prostate and gastric cancers, Annexin A2 has been reported to be upregulated (14-16). It is indicated that Annexin A2 is closely related to cell migration, invasion and adhesion in cancers $(8,17,18)$. Studies have demonstrated that Annexin A2 promoted invasion of tumor cells containing glioma cells, and human hepatocellular carcinoma cells $(8,19)$. Additionally, it is reported that Annexin A2 accelerated proliferation and invasion of human breast cancer SK-BR-3 cells (18). Annexin A2 is indicated to be a predictor of serous ovarian cancer outcome and accelerates ovarian cancer metastasis (20). However, the underlying mechanism of Annexin A2 in cell invasion and proliferation in ovarian cancer is yet to be elucidated.

$\beta$-catenin is a key regulatory factor of the Wnt signaling pathway, and it is claimed that $\beta$-catenin could be regulated by Annexin A2 in hepatoma cells (21). The abnormal function and regulation of $\beta$-catenin could lead to aberrant activation of the Wnt signaling pathway, resulting in abnormalities of gene expression, cell adhesion, and cancer progression (22). Additionally, studies have reported that $\beta$-catenin is closely related to tumorigenesis $(23,24)$. In normal cells, there is only a small amount of free intracellular $\beta$-catenin and it cannot enter the cell nucleus to regulate gene expression. Many studies have shown that $\beta$-catenin is upregulated in many cancers and is associated with poor prognosis (25). The upregulation of 
$\beta$-catenin induces cell proliferation and invasion in cancers such as ovarian cancer, breast cancer, colorectal cancer, and gastric carcinoma (26-30). It has been shown that $\beta$-catenin has an effect on the regulation of EMT (31).

Epithelial-mesenchymal transition (EMT) is demonstrated to be a process whereby epithelial cells change to mesenchymal cells with decreased E-cadherin and increased N-cadherin (32). E-cadherin is the adhesion molecule of epithelial cell surface, and plays an important role in the adhesion between cells (33). The downregulation of E-cadherin is an important feature of EMT (34). Additionally, EMT is a significant cause of tumor invasion and metastasis. Studies have demonstrated that EMT induced cell invasion and proliferation in various cancers such as prostate cancer, breast cancer, colon cancer, and lung cancer $(35,36)$. Moreover, EMT has been claimed to be induced and promote the cell invasion and proliferation in ovarian cancer $(37,38)$.

In this study, we focused on identifying the molecular mechanism of Annexin A2 in cell invasion and proliferation in ovarian cancer. We investigated the expression of Annexin A2 in ovarian cancer tissues and cell lines and revealed the effect of Annexin A2 inhibition on cell invasion and proliferation in ovarian cancer. Additionally, we found that the function of Annexin A2 was realized by regulating EMT via $\beta$-catenin. Annexin A2 may thus be a promising molecular target for the treatment of ovarian cancer.

\section{Materials and methods}

Cell lines and tissues. Human ovarian cancer cell lines SKOV3 and UACC-1598 were purchased from American Type Culture Collection (ATCC, Manassas, VA, USA), and were cultured in RPMI-1640 (Gibco, Carlsbad, CA, USA) with 10\% fetal bovine serum (FBS; PAA Laboraties GmbH, Pasching, Austria) in an atmosphere of $5 \% \mathrm{CO}_{2}$ at $37^{\circ} \mathrm{C}$. The early passages of normal human ovarian epithelial cell line (HOSEpiC) was obtained from ScienCell Research Laboratories (San Diego, CA, USA). HOSEpiC was incubated in the Ovarian Epithelial Cell Medium (OEpiCM) obtained from ScienCell Research Laboratories in the conditions of $5 \% \mathrm{CO}_{2}$ at $37^{\circ} \mathrm{C}$. Additionally, ovarian cancer tissues $(n=10)$ and the matched adjacent normal tissues $(n=10)$ from ovarian cancer patients (aged 30-45 years) with an average age of 39 years in stage II and III were obtained following cryopreservation from the Third Affiliated Hospital of Zhengzhou University along with written informed consent of the patients. This research was approved by the ethics committee at the Third Affiliated Hospital of Zhengzhou University.

Real-time quantitative polymerase chain reaction ( $R T-q P C R)$. The total RNA was extracted by using TRIzol (Takara Biotechnology, Dalian, China), and the extraction of RNA from tissues was performed as previously described (39). Then, the cDNA was synthesized as per the instructions of the reverse transcription kit (Invitrogen, Carlsbad, CA, USA), and the RT-qPCR was subsequently performed. The 25- $\mu 1$ reactive volume contains 10- $\mu$ 1 SsoFast TMEvaGreen Supermix (Bio-Rad, Hercules, CA, USA), and the qRT-PCR protocol was: $94^{\circ} \mathrm{C}$ for $30 \mathrm{sec} ; 35$ cycles of $95^{\circ} \mathrm{C}$ for $30 \mathrm{sec}$, $57^{\circ} \mathrm{C}$ (Annexin $\mathrm{A} 2$ and $\beta$-catenin) or $59^{\circ} \mathrm{C}$ (E-cadherin and
$\mathrm{N}$-cadherin) for $30 \mathrm{sec}$ and $72^{\circ} \mathrm{C}$ for $30 \mathrm{sec}$; and a final step at $72^{\circ} \mathrm{C}$ for $10 \mathrm{~min}$. GAPDH was the internal reference gene. The primers were: Annexin A2 forward, 5'-TAA CTT TGA TGC TGA GCG GG-3' and reverse, 5'-TAA TTT CCT GCA GCT CCT GG-3'; $\beta$-catenin forward, 5'-AAG ACA TCA CTG AGC CTG CCA T-3' and reverse, 5'-CGA TTT GCG GGA CAA AGG GCA A-3'; and GAPDH forward, 5'-GAG TCA ACG GAT TTG GTC GT-3' and reverse, 5'-GAC AAG CTT CCC GTT CTC AG-3'. The relative levels of gene expression were estimated by the $2^{-\Delta \Delta C t}$ method.

Western blotting. Proteins were extracted from the cells by using the lysate and then quantified by using the BCA kit (Pierce, Rockford, IL, USA). The nuclear protein extracts were separated from the homogenates using the NXTRACT CelLytic NuCLEAR Extraction kit (Sigma, St. Louis, MO, USA) according to the standard instructions. A total of $20 \mu \mathrm{g}$ protein was added and isolated in the sodium dodecyl sulfate polyacrylamide gel electrophoresis (12\%). The isolated proteins were transferred to polyvinylidene fluoride membrane (PVDF; Bio-Rad) following electrophoresis. Next, the membrane with proteins was blocked in 5\% non-fat dry milk in Tris-buffered saline for $1.5 \mathrm{~h}$. The blocked membrane was then incubated with the primary antibodies (Cell Signaling Technology, Danvers, MA, USA) at $4^{\circ} \mathrm{C}$ overnight. The membrane was washed with TBS before incubating with horseradish peroxidase conjugated secondary antibody (Cell Signaling Technology). Finally, blots were analyzed in the Bio-Rad ChemiDoc apparatus. The relative protein expression was detected using Image-Pro Plus 6.0.

Construction of recombinant plasmids. Reverse transcription PCR (RT-PCR) was used to amplify the full-length $\beta$-catenin (GenBank accession no. Z19054), and treated with the restriction enzymes $E c o$ RI and BamHI. The $\beta$-catenin fragment was then inserted into the plasmid pcDNA.3.1 (Invitrogen) after which pcDNA.3.1 was treated with EcoRI and BamHI enzymes. Next, the recombinant plasmids were transfected into E. coli DH5 $\alpha$ (Takara Biotechnology) and amplified overnight. Then, the amplified recombinant plasmids were extracted followed by sequencing, and the correct plasmids were designated pcDNA.3.1- $\beta$-catenin.

Transfection of plasmids and siRNA. SKOV3 and UACC-1598 cell lines that were in good condition were respectively plated in the 6-well plate followed by culturing in the atmosphere of $5 \% \mathrm{CO}_{2}$ at $37^{\circ} \mathrm{C}$ for $12 \mathrm{~h}$. The transfection was then conducted when the cell fusion reached $70 \%-80 \%$. pcDNA.3.1- $\beta$-catenin, Annexin A2 siRNA (5'-GGT CTG AAT TCA AGA GAA A-3'), non-specific siRNA or pcDNA.3.1 was diluted in the 150- $\mu$ l FBS-free RPMI-1640 medium with $5 \mu 1$ TurboFect (Thermo Fisher Scientific, Waltham, MA, USA) per well. Subsequently, the transfected cells were cultured in $5 \% \mathrm{CO}_{2}$ at $37^{\circ} \mathrm{C}$ for $48 \mathrm{~h}$. The transfection efficiency was detected via RT-qPCR and western blot assays.

Cell growth. For the detection of cell growth, cells were seeded into a 96 -well plate $\left(1 \times 10^{5}\right.$ cells/well $)$ and subjected to 3-(4,5-dimethylthiazol-2-yl)-2,5-diphenyltetrazolium bromide (MTT) assay. In brief, the transfected cells were cultured 
A

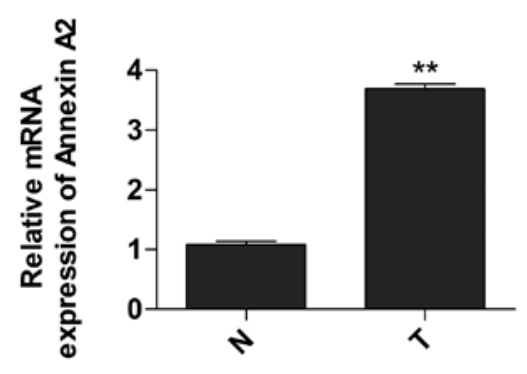

B

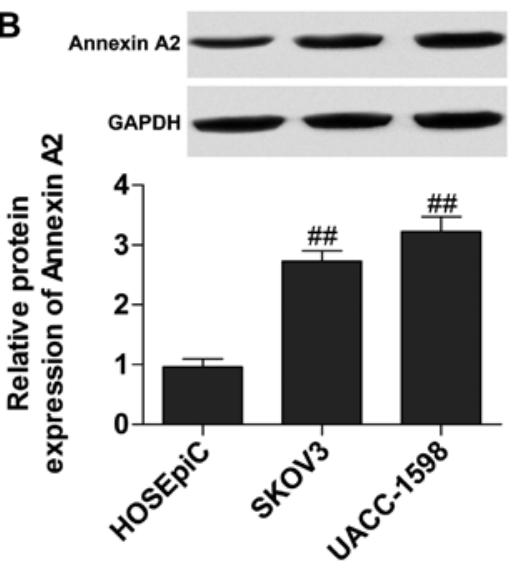

Figure 1. Expression of Annexin A2 in ovarian cancer tissues and cell lines. Relative mRNA (A) and protein (B) expressions of Annexin A2 were measured using RT-qPCR and western blotting, respectively. N, matched adjacent normal tissues; T, tumor tissues. HOSEpiC, HOSEpiC cell line. SKOV3, SKOV3 cell line. UACC-1598, UACC-1598 cell line. GAPDH was used as the internal control. $n=10,{ }^{* *} \mathrm{P}<0.01$ vs. the $\mathrm{N}$ group. $\mathrm{n}=3$, ${ }^{\# \#} \mathrm{P}<0.01 \mathrm{vs}$. the HOSEpiC group.

in humid atmosphere of $5 \% \mathrm{CO}_{2}$ at $37^{\circ} \mathrm{C}$ for $48 \mathrm{~h}$, then the culture medium was replaced by MTT $(5 \mathrm{~g} / \mathrm{l})$ diluted in phosphate-buffered saline (PBS) per well $(23 \mu \mathrm{l})$ and incubated at $37^{\circ} \mathrm{C}$ for $5 \mathrm{~h}$. A total of $200 \mu \mathrm{l}$ dimethyl sulfoxide was added per well to dissolve the formazan, and the absorbance (OD) values were read using an SpectroFluor Plus multiwell plate reader (Tecan, Research Triangle Park, NC, CA, USA) at a wavelength of $490 \mathrm{~nm}$.

Bromodeoxyuridine (BrdU). Cell proliferation was assessed by a BrdU cell proliferation assay kit (Millipore, Billerica, MA, USA) according to the instructions provided. Briefly, the cells were plated in the 96-well plate followed by reaction $(1 \mathrm{~h})$ with $10 \mu \mathrm{l}$ of BrdU solution per well. Thereafter, a total of $100 \mu \mathrm{l}$ denaturing solution was added per well and reacted for $25 \mathrm{~min}$. Cells were then stained with anti-BrdU antibody for $1.5 \mathrm{~h}$ at room temperature followed by staining with secondary antibody solution. Finally, the results were detected at $450 \mathrm{~nm}$ using a SpectroFluor Plus multiwell plate reader (Tecan).

Cell invasion assay. The cell invasion ability was measured by Matrigel invasion assay. Transwell chambers (Corning Incorporated, Toledo, NY, USA) were coated with Matrigel (BD Bioscience, San Jose, CA, USA). The transfected cells were cultured in an incubator (Thermo Fisher Scientific) with $5 \% \mathrm{CO}_{2}$ at $37^{\circ} \mathrm{C}$ for $48 \mathrm{~h}$. Then, the transfected cells were suspended using $300 \mu \mathrm{l}$ serum-free medium ( $1 \times 10^{5}$ cells) and added to the top chamber. Moreover, $500 \mu 1$ of culture medium containing $10 \%$ FBS was added to the bottom chamber and cultured under the conditions of $5 \% \mathrm{CO}_{2}$ at $37^{\circ} \mathrm{C}$ for $48 \mathrm{~h}$. Non-invasive cells in the top chamber were removed and the invaded cells in the bottom chamber were fixed with 95\% ethanol and stained with trypan blue. Finally, six random fields per membrane were chosen and the cells in the fields were counted under a microscope, and then averaged.

Statistical analysis. Data are expressed as the mean \pm standard deviation (SD). Statistical analyses were processed with SPSS version 24.0 software (SPSS Inc., Chicago, IL, USA) with one-way analysis of variance followed by LSD and Bonferroni test. A P-value of $<0.05$ was considered statistically significant.

\section{Results}

Annexin A2 is upregulated in ovarian cancer tissues. We measured the relative expression of mRNA and protein of Annexin A2 in tumor tissues and cell lines, respectively, to investigate the expression of Annexin A2. Data showed that the expression of mRNA (Fig. 1A) and protein (Fig. 1B) of Annexin A2 was significantly increased in tumor tissues and cells.

Suppression of Annexin A2 inhibits $\beta$-catenin. To investigate the effect of Annexin A2 on the expression of $\beta$-catenin, we transfected Annexin A2 siRNA into SKOV3 and UACC-1598 cells to target Annexin A2. The results indicated that expression of mRNA (Fig. 2A and B) and protein (Fig. 2C and D) of Annexin A2 was significantly decreased by the siRNA, and manifested that the transfection was performed successfully. Additionally, the data demonstrated that the relative expression of mRNA (Fig. 2A and B) and protein (Fig. 2C and D) of $\beta$-catenin was markedly suppressed by Annexin A2 inhibition, and the $\beta$-catenin protein contents in nucleus were also decreased after Annexin A2 suppression (Fig. 2E) in SKOV3 and UACC- 1598 cells.

Annexin A2 inhibition restrains the proliferation of ovarian cancer cell lines. To explore the influence of Annexin A2 on ovarian cancer cell lines, we conducted the BrdU and MTT assays to measure SKOV3 and UACC-1598 cell proliferation with Annexin A2 inhibition. The data showed that the proliferation of SKOV3 and UACC-1598 cells in the BrdU assay was obviously constrained by Annexin A2 suppression (Fig. 3A). In addition, cell proliferation was also significantly decreased in the MTT assay (Fig. 3B).

Annexin A2 inhibition decreases the invasion ability of ovarian cancer cell lines. To gain insight into the potential role of Annexin A2 in ovarian cancer cell line invasion ability, we detected the invasion by EMT measurement and invasion assay in SKOV3 and UACC-1598 cells with Annexin A2 inhibition. In EMT measurement by using western blotting, we found that the protein expression of E-cadherin was obviously 

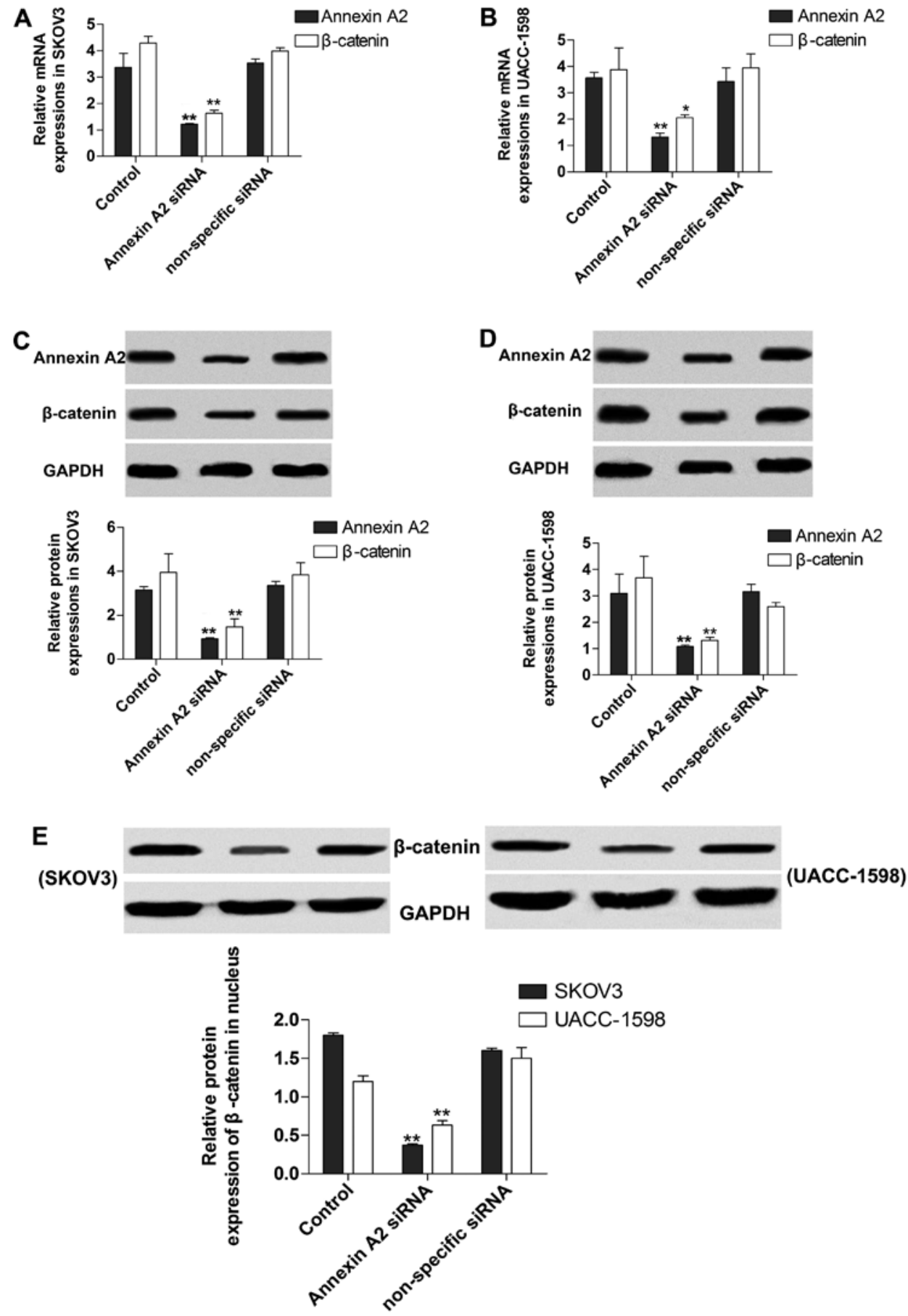

Figure 2. Expression of $\beta$-catenin in ovarian cancer cell lines with Annexin A2 inhibition. The relative mRNA levels in SKOV3 (A) and UACC-1598 (B) of Annexin A2 and $\beta$-catenin were measured by qRT-PCR. The relative protein levels in SKOV3 (C) and UACC-1598 (D) of Annexin A2 and $\beta$-catenin were measured by western blot analyses. (E) $\beta$-catenin protein content in nucleus of SKOV3 and UACC-1598 cell lines were measured by western blot analyses. Control, SKOV3 or UACC-1598 cells without transfection. Annexin A2 siRNA, SKOV3 or UACC-1598 cells transfected with Annexin A2 siRNA. Non-specific siRNA, SKOV3 or UACC-1598 cells transfected with non-specific siRNA. GAPDH was used as the control. $n=3,{ }^{*} \mathrm{P}<0.05$ and ${ }^{* *} \mathrm{P}<0.01$ vs. non-specific siRNA group.

increased while $\mathrm{N}$-cadherin was significantly decreased by Annexin A2 inhibition (Fig. 4A and B). In the invasion assay, cell invasion ability was markedly constrained by the suppression of Annexin A2 (Fig. 4C).

Annexin A2 inhibition suppresses EMT through controlling $\beta$-catenin expression. To further explore the molecular mechanism of Annexin A2 in the regulation of EMT in ovarian cancer cell lines, we transfected pcDNA.3.1- $\beta$-catenin into the SKOV3 and UACC-1598 cells with Annexin A2 inhibition. The data showed that $\beta$-catenin protein expression was markedly increased, whereas Annexin A2 was decreased in the treated SKOV3 (Fig. 5A) and UACC-1598 (Fig. 5B), indicating that the transfection of pcDNA.3.1- $\beta$-catenin was successful. Additionally, we found that the suppressive effect of Annexin A2 inhibition on EMT was apparently reversed by pcDNA.3.1- $\beta$-catenin transfection (Fig. 6A and B). Moreover, $\beta$-catenin overexpression obviously abolished the 

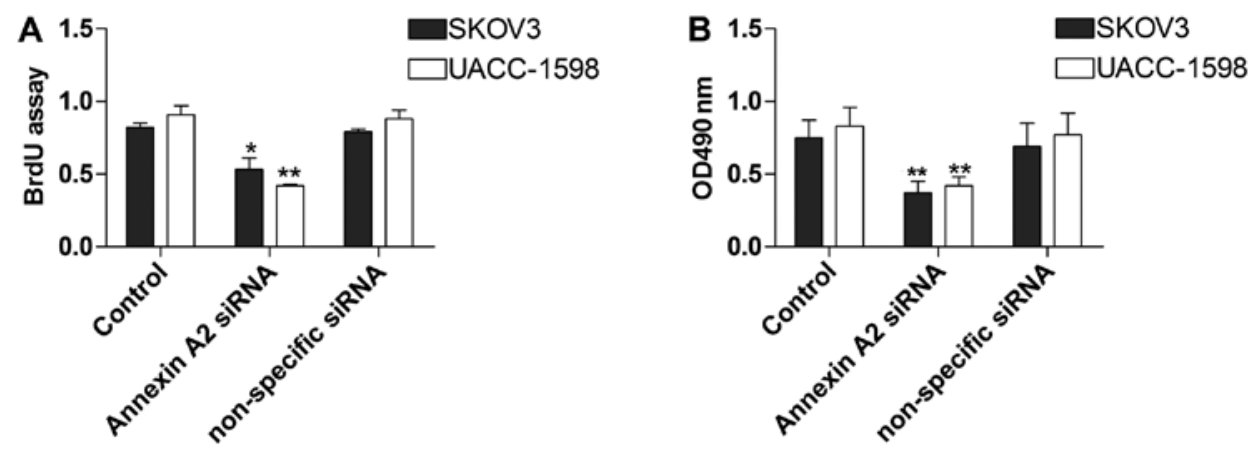

Figure 3. The proliferation of ovarian cancer cells with Annexin A2 inhibition. The cell proliferation was detected by BrdU (A) and MTT (B) assays in SKOV3 and UACC-1598 with Annexin A2 inhibition. $n=3,{ }^{*} \mathrm{P}<0.05$ and ${ }^{* *} \mathrm{P}<0.01$ vs. the non-specific siRNA group.
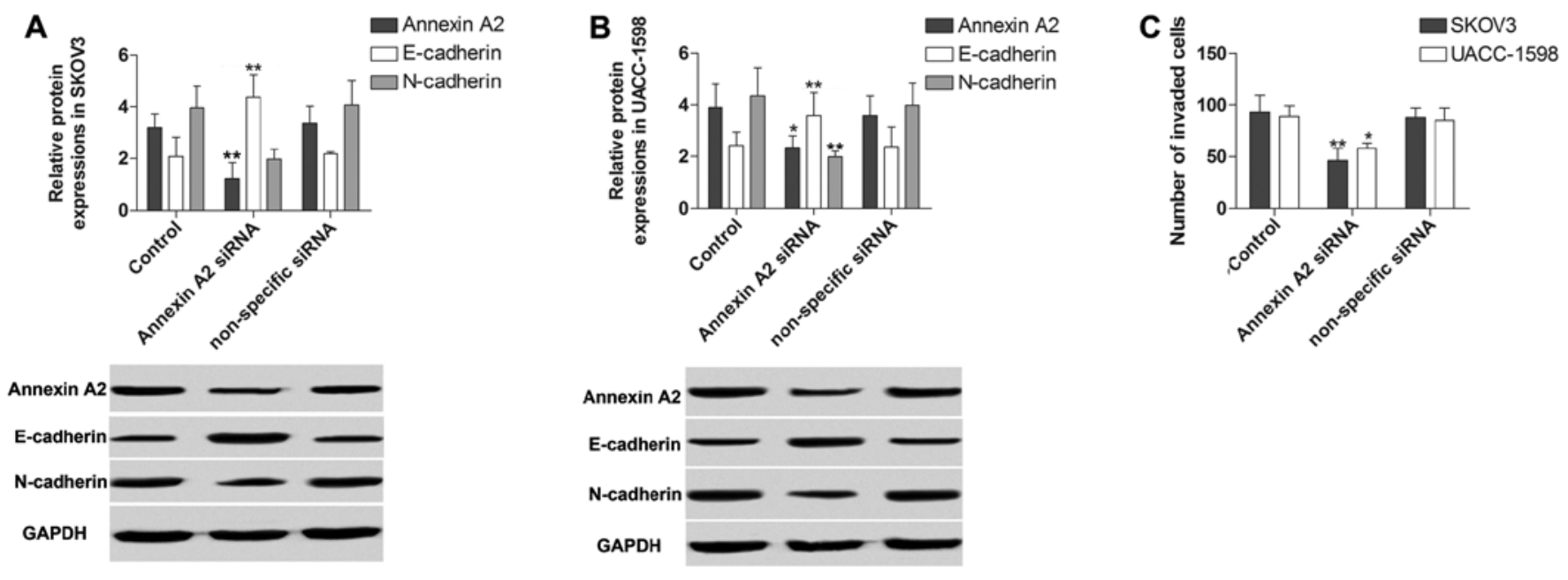

Figure 4. The invasion of the ovarian cancer cells with Annexin A2 inhibition. The cell invasion was detected by EMT measurement (A and B) and invasion (C) assay in SKOV3 and UACC-1598 with Annexin A2 inhibition. The GAPDH was used as the internal control. $n=3,{ }^{*} \mathrm{P}<0.05$ and ${ }^{* *} \mathrm{P}<0.01$ vs. the non-specific siRNA group.
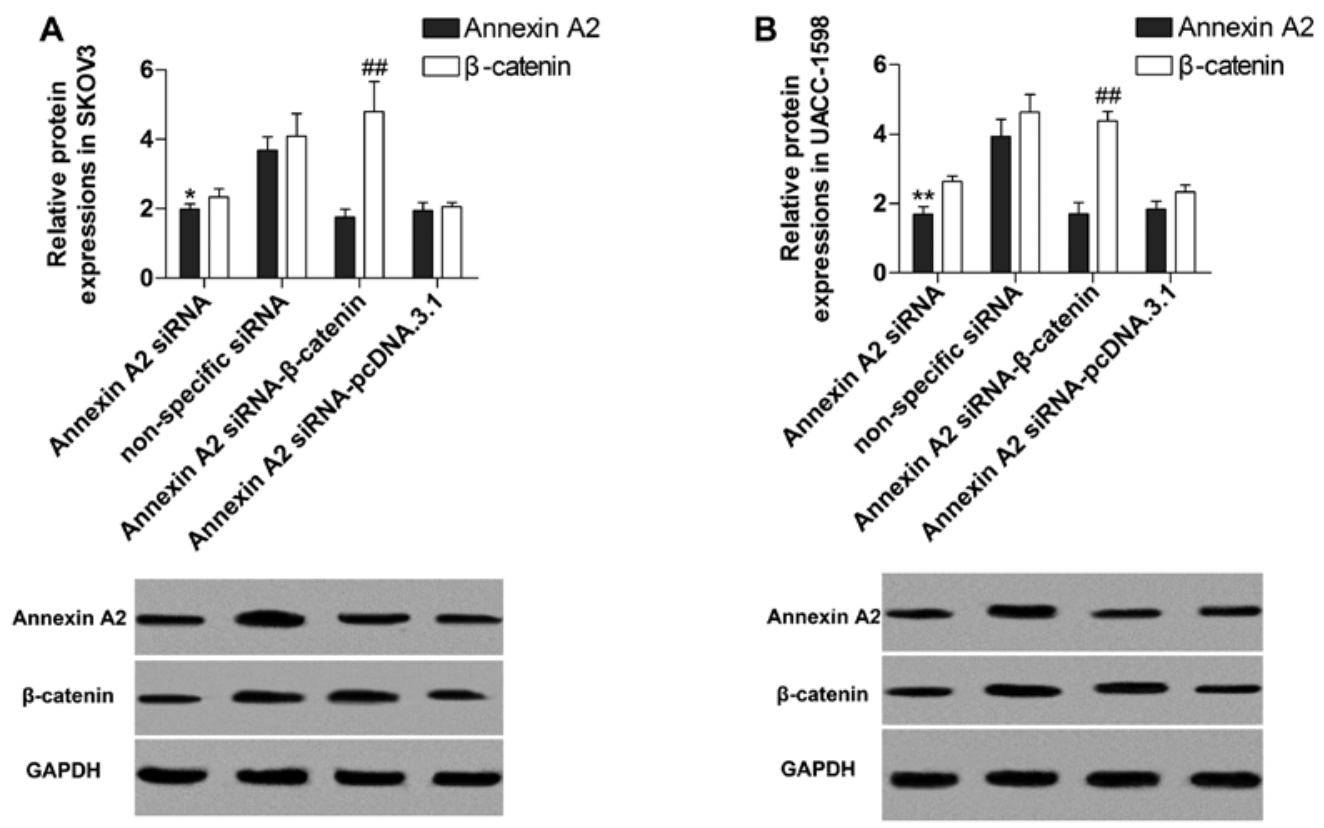

Figure 5. Protein expression in the ovarian cancer cell lines with Annexin A2 inhibition and $\beta$-catenin overexpression. Protein expression of Annexin A2 and $\beta$-catenin in SKOV3 (A) and UACC-1598 (B) with Annexin A2 inhibition and $\beta$-catenin overexpression were detected by western blotting. Annexin A2 siRNA- $\beta$-catenin, the SKOV3 or UACC-1598 with Annexin A2 inhibition transfected with pcDNA.3.1- $\beta$-catenin. Annexin A2 siRNA-pcDNA.3.1, the SKOV3 or UACC-1598 with Annexin A2 inhibition transfected with pcDNA.3.1. GAPDH was used as the internal control. $\mathrm{n}=3$, ${ }^{*} \mathrm{P}<0.05$ and ${ }^{* * *} \mathrm{P}<0.01 \mathrm{vs}$. the nonspecific siRNA group. ${ }^{\# \#} \mathrm{P}<0.01$ vs. Annexin A2 siRNA-pcDNA.3.1 group. 

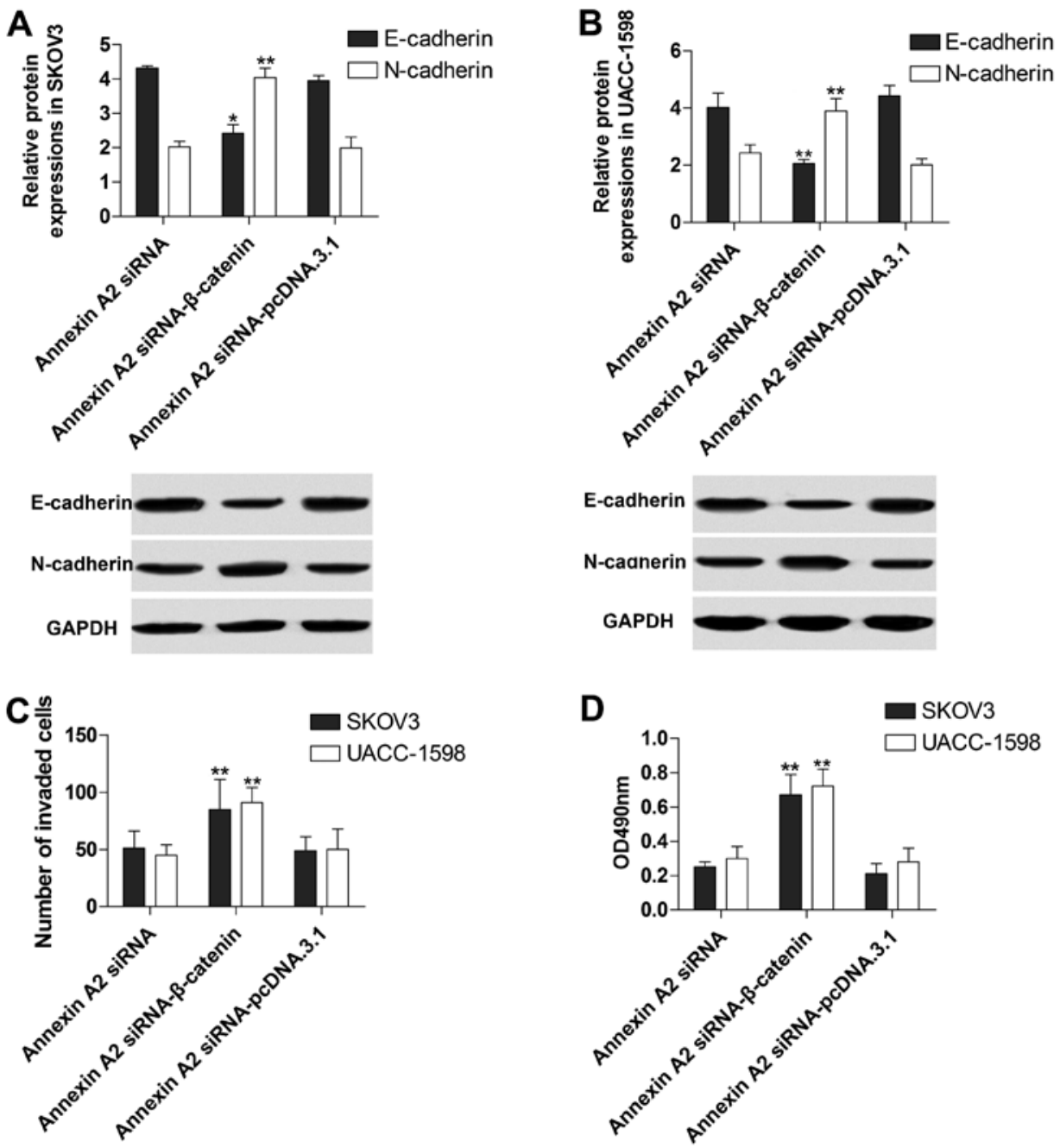

Figure 6. The effect of Annexin A2 inhibition and $\beta$-catenin overexpression in the ovarian cancer cell lines on EMT, invasion and proliferation. EMT measurements in SKOV3 (A) and UACC-1598 (B) with Annexin A2 inhibition and $\beta$-catenin overexpression were performed using western blotting. The invasion (C) and proliferation (D) in SKOV3 and UACC-1598 with Annexin A2 inhibition and $\beta$-catenin overexpression were detected by invasion and MTT assays, respectively. GAPDH was used as the internal control. $n=3,{ }^{*} \mathrm{P}<0.05$ and ${ }^{* *} \mathrm{P}<0.01$ vs. the Annexin A2 siRNA-pcDNA.3.1 group.

inhibitory influence of Annexin A2 inhibition to the invasion (Fig. 6C) and proliferation (Fig. 6D) of SKOV3 and UACC-1598 cells.

\section{Discussion}

Because of the dietary structure, environmental pollution and other factors, ovarian cancer morbidity is increasing year by year $(40,41)$. Annexins are widely involved in regulating cell membrane construction and material transport (9). Additionally, Annexins have been indicated to be involved in the development of tumors (42). It has been demonstrated that Annexin A2 is a potential prognostic factor, and has a stimulatory effect on ovarian cancer. Moreover, Annexin A2 is reported to promote cell proliferation and invasion in breast cancer (43). Currently, the role and underlying mechanism of Annexin A2 in cell proliferation and invasion in ovarian cancer is unclear. In our study, Annexin A2 was significantly increased in ovarian cancer tissues and cells in accordance with the above reports. Besides, we found that cell proliferation and invasion in ovarian cancer were both obviously constrained in the loss-of-function experiment of Annexin A2.
Annexin A2 has been indicated to regulate the expression of $\beta$-catenin.

$\beta$-catenin, which is located on human chromosome $3 \mathrm{p} 21$, and plays a pivotal role in the classic Wnt signaling pathway (44). The major $\beta$-catenin in the cytoplasm forms the adhesion complex with E-cadherin inside the cell membrane, and the level of dissociative $\beta$-catenin content in normal cells is low (45). It is reported that $\beta$-catenin is increased in malignant tumors such as breast cancer, colon cancer, and gastrointestinal cancer (46-48). Additionally, $\beta$-catenin could regulate EMT in cancers, and is demonstrated to promote EMT in gastric cancer $(29,31,49,50)$. In our study, we observed that the expression in cell and the nucleus content of $\beta$-catenin was significantly decreased by Annexin A2 downregulation. In addition, the results showed that $\beta$-catenin overexpression markedly reversed the inhibitory effect of Annexin A2 suppression on EMT. Thus, the data indicated that Annexin A2 could regulate EMT via controlling $\beta$-catenin in ovarian cancer. ConacciSorrell et al indicated that the strong $\beta$-catenin/TCF signaling promoted the expression of Slug causing the suppression of E-cadherin expression in sparse SW480 cells, accelerating the process of EMT (51). In our study, $\beta$-catenin inhibition realizes 
the promoted function on E-cadherin, resulting in the suppression of EMT, consisting with that found in sparse SW480 cells. Thus, we considered that $\beta$-catenin inhibition possibly decreases Slug expression and then increases E-cadherin, resulting in the suppression of EMT.

EMT is the morphological process where epithelial cells transform into mesenchymal cells, and the imbalance of EMT plays an important role in invasion and metastatic processes in cancer (36). In the EMT process, cancer cells access migration and invasion and obtain the characteristics of stem cells through a loss of cell-cell adhesion and cell polarity, transforming into the mesenchymal-like cell morphology(51). Studies have reported that EMT acts as the driver of invasion and metastasis in cancers (52). Furthermore, EMT has been revealed to modulate the invasion and proliferation of cells in colorectal cancer $(53,54)$. In our study, EMT was inhibited while the loss-of-function experiment of Annexin A2 was performed, and the invasion and proliferation were both constrained in ovarian cancer cells. In addition, overexpression of $\beta$-catenin abolished the suppressive function of Annexin A2 on EMT, while the cell invasion and proliferation were promoted. Based on the above, Annexin A2 inhibition could constrain cell invasion and proliferation via regulating $\beta$-catenin/EMT in ovarian cancer.

In conclusion, this study found that Annexin A2 expression is accelerated in ovarian cancer tissues and cell lines. Annexin A2 suppression has an inhibitory effect on EMT and cell invasion and proliferation. Additionally, Annexin A2 regulation of EMT could been realized by controlling $\beta$-catenin. Therefore, the potential role of Annexin A2 in ovarian cancer is revealed and provides novel insight into the treatment of ovarian cancer.

\section{References}

1. Lowe KA, Chia VM, Taylor A, O'Malley C, Kelsh M, Mohamed M, Mowat FS and Goff B: An international assessment of ovarian cancer incidence and mortality. Gynecol Oncol 130: 107-114, 2013.

2. Anugraham M, Jacob F, Nixdorf S, Everest-Dass AV, Heinzelmann-Schwarz V and Packer NH: Specific glycosylation of membrane proteins in epithelial ovarian cancer cell lines: Glycan structures reflect gene expression and DNA methylation status. Mol Cell Proteomics 13: 2213-2232, 2014.

3. Liang Y, Aebi J, Nephew K and Hyder SM: Targeting cholesterol biosynthesis pathway to inhibit growth of drug resistant ovarian cancer cells. Cancer Res 76 (Suppl. 14): 3789, 2016.

4. Gilbert L, Basso O, Sampalis J, Karp I, Martins C, Feng J, Piedimonte S, Quintal L, Ramanakumar AV, Takefman J, et al; DOvE Study Group: Assessment of symptomatic women for early diagnosis of ovarian cancer: Results from the prospective DOvE pilot project. Lancet Oncol 13: 285-291, 2012.

5. Kumar S, Meuter A, Thapa P, Langstraat C, Giri S, Chien J, Rattan R, Cliby W and Shridhar V: Metformin intake is associated with better survival in ovarian cancer: A case-control study. Cancer 119: 555-562, 2013.

6. Yang J, Yang F, Nie J, Zou X, Tian H, Qin Y and Liu C: Evaluation of Annexin A2 as a novel diagnostic serum biomarker for lung cancer. Cancer Biomark 15: 205-211, 2015.

7. Xu D, Sun L, Liu S, Zhang L and Yang H: Histological, ultrastructural and heat shock protein 70 (HSP70) responses to heat stress in the sea cucumber Apostichopus japonicus. Fish Shellfish Immunol 45: 321-326, 2015.

8. Onishi M, Ichikawa T, Kurozumi K, Inoue S, Maruo T, Otani Y, Fujii K, Ishida J, Shimazu Y, Yoshida K, et al: Annexin A2 regulates angiogenesis and invasion phenotypes of malignant glioma. Brain Tumor Pathol 32: 184-194, 2015.

9. Liu W and Hajjar KA: The Annexin A2 system and angiogenesis. Biol Chem 397: 1005-1016, 2016.
10. Dai H, Yu Z, Fan X, Liu N, Yan M, Chen Z, Lo EH, Hajjar KA and Wang X: Dysfunction of Annexin A2 contributes to hyperglycaemia-induced loss of human endothelial cell surface fibrinolytic activity. Thromb Haemost 109: 1070-1078, 2013.

11. Bharadwaj A, Bydoun M, Holloway R and Waisman D: Annexin A2 heterotetramer: Structure and function. Int J Mol Sci 14: 6259-6305, 2013.

12. Yamashita K, Nagai H and Toyokuni S: Receptor role of the Annexin A2 in the mesothelial endocytosis of crocidolite fibers. Lab Invest 95: 749-764, 2015.

13. Kantara C, O'Connell MR, Luthra G, Gajjar A, Sarkar S, Ullrich RL and Singh P: Methods for detecting circulating cancer stem cells (CCSCs) as a novel approach for diagnosis of colon cancer relapse/metastasis. Lab Invest 95: 100-112, 2015.

14. Zhang F, Wang Z, Yuan J, Wei X, Tian R and Niu R: RNAi-mediated silencing of Anxa2 inhibits breast cancer cell proliferation by downregulating cyclin D1 in STAT3-dependent pathway. Breast Cancer Res Treat 153: 263-275, 2015.

15. Deng Y, Chen C, Hua M, Xi Q, Liu R, Yang S, Liu J, Zhong J, Tang M, Lu S, et al: Annexin A2 plays a critical role in epithelial ovarian cancer. Arch Gynecol Obstet 292: 175-182, 2015.

16. Zhang Q, Ye Z, Yang Q, He X, Wang H and Zhao Z: Upregulated expression of annexin II is a prognostic marker for patients with gastric cancer. World J Surg Oncol 10: 103, 2012.

17. Xiu D, Liu L, Qiao F, Yang H, Cui L and Liu G: Annexin A2 coordinates STAT3 to regulate the invasion and migration of colorectal cancer cells in vitro. Gastroenterol Res Pract 2016: 3521453, 2016.

18. Wang YQ, Zhang F, Tian R, Ji W, Zhou Y, Sun XM, Liu Y, Wang ZY and Niu RF: Tyrosine 23 phosphorylation of Annexin A2 promotes proliferation, invasion, and Stat 3 phosphorylation in the nucleus of human breast cancer SK-BR-3 cells. Cancer Biol Med 9: 248-253, 2012

19. Zhang W, Zhao P, Xu XL, Cai L, Song ZS, Cao DY, Tao KS, Zhou WP, Chen ZN and Dou KF: Annexin A2 promotes the migration and invasion of human hepatocellular carcinoma cells in vitro by regulating the shedding of CD147-harboring microvesicles from tumor cells. PLoS One 8: e67268, 2013.

20. Lokman NA, Elder AS, Ween MP, Pyragius CE, Hoffmann P, Ruszkiewicz A, Ricciardelli C and Oehler MK: Annexin A2, a potential prognostic marker for serous ovarian cancer promotes ovarian cancer metastasis. In: Clinical and Experimental Medicine. Springer, Dordrecht, pp220-220, 2015.

21. Wang C, Guo Y, Wang J and Min Z: Annexin A2 knockdown inhibits hepatoma cell growth and sensitizes hepatoma cells to 5 -fluorouracil by regulating $\beta$-catenin and cyclin D1 expression. Mol Med Rep 11: 2147-2152, 2015.

22. Amini-Nik S, Cambridge E, Yu W, Guo A, Whetstone $\mathrm{H}$, Nadesan P, Poon R, Hinz B and Alman BA: $\beta$-Catenin-regulated myeloid cell adhesion and migration determine wound healing. J Clin Invest 124: 2599-2610, 2014.

23. Llado V, Nakanishi Y, Duran A, Reina-Campos M, Shelton PM, Linares JF, Yajima T, Campos A, Aza-Blanc P, Leitges M, et al: Repression of intestinal stem cell function and tumorigenesis through direct phosphorylation of $\beta$-catenin and Yap by PKC $\zeta$. Cell Rep 10: 740-754, 2015.

24. Kang DW, Choi CY, Cho YH, Tian H, Di Paolo G, Choi KY and Min S: Targeting phospholipase D1 attenuates intestinal tumorigenesis by controlling $\beta$-catenin signaling in cancer-initiating cells. J Exp Med 212: 1219-1237, 2015.

25. Zhu G, Wang Y, Huang B, Liang J, Ding Y, Xu A and Wu W: A Rac1/PAK1 cascade controls $\beta$-catenin activation in colon cancer cells. Oncogene 31: 1001-1012, 2012.

26. Chen BY, Wang X, Wang ZY, Wang YZ, Chen LW and Luo ZJ: Brain-derived neurotrophic factor stimulates proliferation and differentiation of neural stem cells, possibly by triggering the Wnt/ß-catenin signaling pathway. J Neurosci Res 91: 30-41, 2013.

27. Simic P, Zainabadi K, Bell E, Sykes DB, Saez B, Lotinun S, Baron R, Scadden D, Schipani E and Guarente L: SIRT1 regulates differentiation of mesenchymal stem cells by deacetylating $\beta$-catenin. EMBO Mol Med 5: 430-440, 2013.

28. Wend P, Runke S, Wend K, Anchondo B, Yesayan M, Jardon M, Hardie N, Loddenkemper C, Ulasov I, Lesniak MS, et al: WNT10B/ $\beta$-catenin signalling induces HMGA2 and proliferation in metastatic triple-negative breast cancer. EMBO Mol Med 5: 264-279, 2013

29. Huang J, Xiao D, Li G, Ma J, Chen P, Yuan W, Hou F, Ge J, Zhong M, Tang Y, et al: EphA2 promotes epithelial-mesenchymal transition through the $\mathrm{Wnt} / \beta$-catenin pathway in gastric cancer cells. Oncogene 33: 2737-2747, 2014. 
30. Nagaraj AB, Joseph P, Kovalenko O, Singh S, Armstrong A, Redline R, Resnick K, Zanotti K, Waggoner S and DiFeo A: Critical role of $\mathrm{Wnt} / \beta$-catenin signaling in driving epithelial ovarian cancer platinum resistance. Oncotarget 6: 23720-23734, 2015.

31. Guo Q and Qin W: DKK3 blocked translocation of $\beta$-catenin/ EMT induced by hypoxia and improved gemcitabine therapeutic effect in pancreatic cancer Bxpc-3 cell. J Cell Mol Med 19: 2832-2841, 2015

32. Rogers CD, Saxena A and Bronner ME: Sip1 mediates an E-cadherin-to-N-cadherin switch during cranial neural crest EMT. J Cell Biol 203: 835-847, 2013.

33. McEwen AE, Maher MT, Mo R and Gottardi CJ: E-cadherin phosphorylation occurs during its biosynthesis to promote its cell surface stability and adhesion. Mol Biol Cell 25: 2365-2374, 2014.

34. Zhang K, Yang G, Wu W, Zhang J, Xia X, Jiang T, Cao J, Huang K, Qiu Z and Huang C: Decreased expression of caveolin-1 and E-cadherin correlates with the clinicopathologic features of gastric cancer and the EMT process. Recent Patents Anticancer Drug Discov 11: 236-244, 2016.

35. Xia Y, Wu Y, Liu B, Wang P and Chen Y: Downregulation of miR-638 promotes invasion and proliferation by regulating SOX2 and induces EMT in NSCLC. FEBS Lett 588: 2238-2245, 2014.

36. Rokavec M, Öner MG, Li H, Jackstadt R, Jiang L, Lodygin D, Kaller M, Horst D, Ziegler PK, Schwitalla S, et al: IL-6R/STAT3/ miR-34a feedback loop promotes EMT-mediated colorectal cancer invasion and metastasis. J Clin Invest 124: 1853-1867, 2014.

37. Mao Y, Xu J, Li Z, Zhang N, Yin $\mathrm{H}$ and Liu Z: The role of nuclear $\beta$-catenin accumulation in the Twist 2 -induced ovarian cancer EMT. PLoS One 8: e78200, 2013.

38. Lili LN, Matyunina LV, Walker LD, Wells SL, Benigno BB and McDonald JF: Molecular profiling supports the role of epithelialto-mesenchymal transition (EMT) in ovarian cancer metastasis. J Ovarian Res 6: 49, 2013.

39. Li YL, Ye F, Hu Y, Lu WG and Xie X: Identification of suitable reference genes for gene expression studies of human serous ovarian cancer by real-time polymerase chain reaction. Anal Biochem 394: 110-116, 2009.

40. Xie J, Poole EM, Terry KL, Fung TT, Rosner BA, Willett WC and Tworoger SS: A prospective cohort study of dietary indices and incidence of epithelial ovarian cancer. J Ovarian Res 7: 112, 2014.

41. García-Pérez J, Lope V, López-Abente G, González-Sánchez M and Fernández-Navarro P: Ovarian cancer mortality and industrial pollution. Environ Pollut 205: 103-110, 2015.
42. Peng B, Guo C, Guan H, Liu S and Sun MZ: Annexin A5 as a potential marker in tumors. Clin Chim Acta 427: 42-48, 2014

43. Wu B, Zhang F, Yu M, Zhao P, Ji W, Zhang H, Han J and Niu R: Up-regulation of Anxa2 gene promotes proliferation and invasion of breast cancer MCF-7 cells. Cell Prolif 45: 189-198, 2012.

44. Mei XD, Su H, Song J and Dong L: Prognostic significance of $\beta$-catenin expression in patients with non-small cell lung cancer: A meta-analysis. Biosci Trends 7: 42-49, 2013.

45. Sempou E, Biasini E, Pinzón-Olejua A, Harris DA and MálagaTrillo E: Activation of zebrafish Src family kinases by the prion protein is an amyloid- $\beta$-sensitive signal that prevents the endocytosis and degradation of E-cadherin/ $\beta$-catenin complexes in vivo. Mol Neurodegener 11: 18, 2016.

46. Siemens H, Neumann J, Jackstadt R, Mansmann U, Horst D, Kirchner T and Hermeking H: Detection of miR-34a promoter methylation in combination with elevated expression of c-Met and $\beta$-catenin predicts distant metastasis of colon cancer. Clin Cancer Res 19: 710-720, 2013.

47. Yan D, Avtanski D, Saxena NK and Sharma D: Leptin-induced epithelial-mesenchymal transition in breast cancer cells requires $\beta$-catenin activation via Akt/GSK3- and MTA1/Wnt1 proteindependent pathways. J Biol Chem 287: 8598-8612, 2012.

48. Zheng H, Li W, Wang Y, Liu Z, Cai Y, Xie T, Shi M, Wang Z and Jiang B: Glycogen synthase kinase-3 beta regulates Snail and $\beta$-catenin expression during Fas-induced epithelial-mesenchymal transition in gastrointestinal cancer. Eur J Cancer 49: 2734-2746, 2013.

49. Zha L, Zhang J, Tang W, Zhang N, He M, Guo Y and Wang Z: HMGA2 elicits EMT by activating the Wnt/ $\beta$-catenin pathway in gastric cancer. Dig Dis Sci 58: 724-733, 2013.

50. Cheung CT, Bendris N, Paul C, Hamieh A, Anouar Y, Hahne M, Blanchard JM and Lemmers B: Cyclin A2 modulates EMT via $\beta$-catenin and phospholipase $\mathrm{C}$ pathways. Carcinogenesis 36 : 914-924, 2015

51. Conacci-Sorrell M, Simcha I, Ben-Yedidia T, Blechman J, Savagner P and Ben-Ze'ev A: Autoregulation of E-cadherin expression by cadherin-cadherin interactions: The roles of $\beta$-catenin signaling, Slug, and MAPK. J Cell Biol 163: 847-857, 2003.

52. Huang RY, Guilford P and Thiery JP: Early events in cell adhesion and polarity during epithelial-mesenchymal transition. J Cell Sci 125: 4417-4422, 2012.

53. Biddle A and Mackenzie IC: Cancer stem cells and EMT in carcinoma. Cancer Metastasis Rev 31: 285-293, 2012.

54. Zou J, Luo H, Zeng Q, Dong Z, Wu D and Liu L: Protein kinase CK2 $\alpha$ is overexpressed in colorectal cancer and modulates cell proliferation and invasion via regulating EMT-related genes. J Transl Med 9: 97, 2011. 